\title{
THE ROLE OF CARTOON IN THE FORMATION OF ASIAN COMMUNITY: ART HISTORY ANALYSIS
}

\section{Muliyadi Mahamood ${ }^{1}$}

\begin{abstract}
Cartoon art is a form of visual communication that can effectively convey a message and social criticism. In the Malaysian context, the editorial cartoons have been proven as effective since the beginning of independence until now. Even so, the form and style of criticism have always been changing through the time and are influenced by environmental, socio-political, legal and media ownership factors. Through formalistic and contextual analysis of selected works from Malaysia, particularly in Lat cartoons, this paper seeks survey and examines the existence of Asian cartoon style role towards the formation of the Asian community.
\end{abstract}

Key Words: cartoon, Asian Community, art history

${ }^{1}$ Muliyadi Mahamood, Professor of Visual Culture, Universiti Teknologi MARA (UiTM) Malaysia. For academic interest, the author can be contacted at office address: Puncak Alam, 42300 Bandar Puncak Alam, Selangor, Malaysia. 


\section{Introduction}

"Western Lives in the West, East Stays in the East" is the title that appears at the top of the editorial cartoon created by Abd. Manan in Warta Jenaka, a newspaper of humor published on September 7, 1936. Words that have big meanings in interpreting the Oriental spirit arisen before the independence era. In this work, animal imagery had been used in connection to convey political and cultural ideas. Malay people who really adored the glorify of Western culture were symbolized as apes dressed in Western-style clothing, and apparently turned out to be imperfect and totally awkward. Malay people who behaved Western attitude and applied Western cultures considered themselves higher than other Malay, and this phenomenon had been criticized to have harsh style through the anthropomorphic characters such as this (Illustration 8.1).

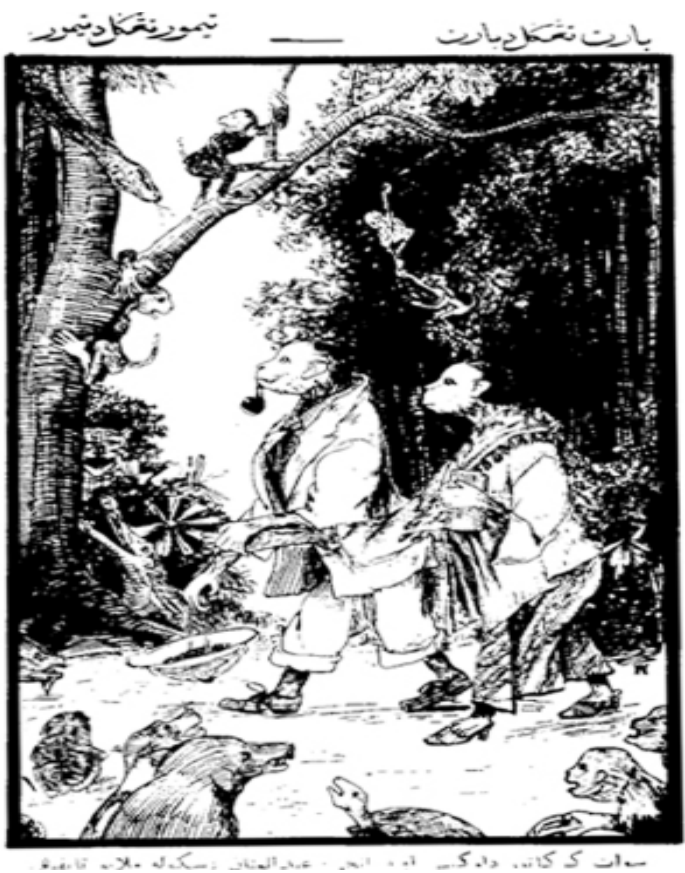

Illustration 8.1. Abd. Manan, Warta Jenaka, September 7, 1936.
In the pre-independence era (before 1957), the issue of modernity and Westernisation had become the main subject matter in the cartoon artwork and literature in Malaysia (Illustration 2). Literature and art in the cartoon had also become platform for criticizing those who forgot the roots of the culture and values of the East. Literary works such as novel Pak Sako Putera Gunung Tahan (1938) had symbolically criticized the Malay aristocracy and the Malay community in general who had forgotten the roots of their religion and culture. These groups of people were characterized as a colonial contrivance that could erode their own national culture.

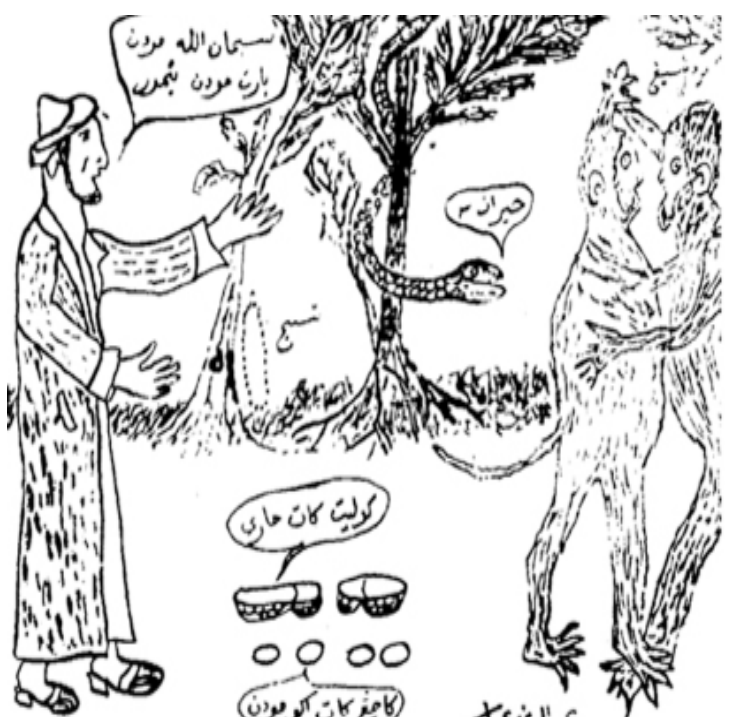

Illustration 8.2. Abdullah Abas, Warta Jenaka, November 23, 1936.

Now in this new millennium, we are still talking about the search for identity, especially the identity of Asia in the global nature of the good life and without borders. What are the possibilities that we can do in the context of the discipline of art and design in order to achieve this objective? In the context of this paper, I will review the work of cartoons based 
on the Malaysian experience. Through formalistic and contextual research on Malaysia cartoon works, particularly the works of Lat, this paper aims to identify the universal elements and especially Asia in translating criticism- the message and meaning towards the formation of the Asian community.

\section{Contextual Factors of Art Style Formation and Meaning in Malaysia}

In the development of visual arts in Malaysia, there are many contextual factors that have influenced the art style and meaning. In the early stages, colonization, migration and education were among the main factors. The arrival of the British in the end of the 1920s has influenced the early modern art, that focused its creativity on the production of many watercolor paintings that depict the beauty of nature and local treasure of Malaysia, while the immigration of Chinese painters in the late 1930s has also contributed to the emergence of Western style in art, such as the influence impressionism and post impressionism and the featured of Nanyang impressionist painters.

Painters who returned from studying abroad, such as Syed Ahmad Jamal, Tay Hooi Keat, Ismail Zain Ibrahim Hussein and Abdul Latif Mohidin in the decades of 1960 s built the emergence of expressionism and abstract expressionism style in Malaysia. Although influenced by Western styles, local identity manifested through the selection of local and regional subjects as calligraphy elements appeared in the works of Syed Ahmad Jamal. Before the independence, the growth of art and many informal art education groups had been led by artists such as Wednesday Art Group and Peninsula Painters.
Wednesday Art Group has emphasized the independence of regional imagery based on artistic expression, while Peninsula Painters have enforced art as a means of channeling the nation's cultural values, in keeping with the spirit of independence in 1957. Government commitment to the importance of art, then reflected through the establishment of the National Art Gallery in 1958.

For the field of cartoon art, the editorial cartoon has become meaningful sociopolitical weapon since preindependence through the appearance of works that against the occupation and severe criticism to the society and government. Bad attitude: lazy, shy, uncomprehended religious teachings, and love debt, had been criticized as factors that have constrained the progress of the nation (Illustration 8.3).

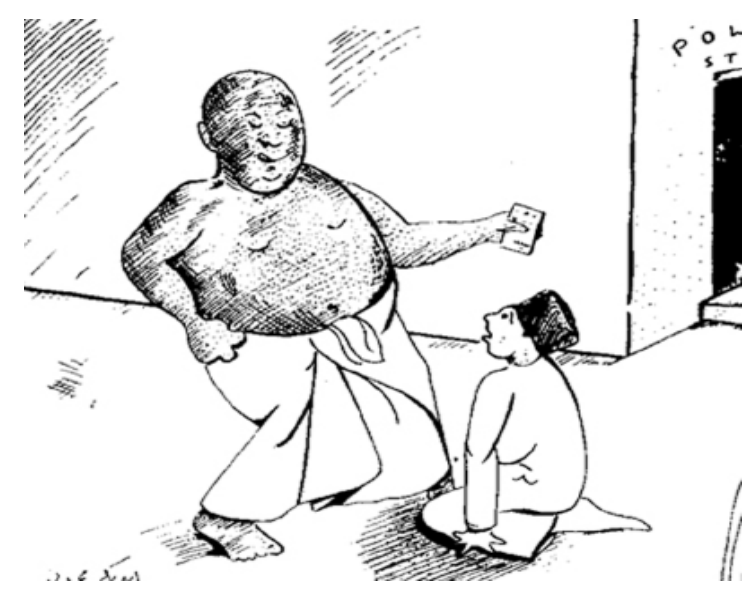

Illustration 8.3. Abu Bakar Mohd. Nor, Warta Jenaka, September 14, 1936

Nevertheless, the post-independence era saw the works of more moderate cartoon in promoting the spirit of national unity in a newly independent country. Slopes cartoon series also featured a family theme through more polite and relaxed jokes, as in the series of "Mat Jambul Family 
(Keluarga)" by Raja Hamzah (Illustration 4). In this context, the influence of English humor and cartoons, aspects of local culture and modernity also affected the work, in addition to the press policies that more favorable to the government.

Malaysian Cartoon art developments should be divided into four important eras, namely Pioneer Era (1930s to 1957), New Era (1957 to 1970), Glory era (the 1980s), and the Pluralist Era (Since the 1990 s ). In this context, cartoon style and principlehave also changed in parallel with the development of the state, society, culture, socio-political, technological and media ownership. At the beginning, cartoons were only published in the print media, animation, but later, in the form of electronic media, and up until now, they are developed in various other forms such as digital media and the internet.

History has shown that the cartoon art in this country has gone through various stages of development of the genre, style, theme, form, meaning, and witty. Art has become a sidelinein film magazines and entertainment, cartoon art has a foothold as an important genre of visual art on its own. This situation is evidenced by the emergence of specialized magazines that magnitude numbers since the end of the 1970s decades up to the present, such as the Gila-Gila (Crazy-Crazy), Gelihati (Gigling), Batu Api (Fire Stone), Mat Jenin, Humor, Ujang, Apo, Gempak, Utopia, Starz, JOM, and G3, and supported by the emergence of many animated works. Filmed the story of daily life as well as the various characters, nations and cultures have been able to reflect the country's diverse and pluralist communities.

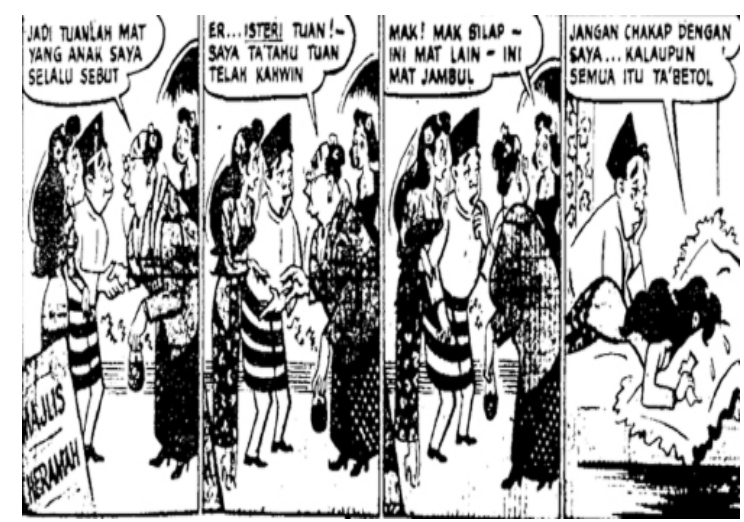

Illustration 8.4. Raja Hamzah, "Keluarga Mat Jambul" in the Daily News, July 1, 1957.

During the decades of the 1960s, a trend towards the significance of art and design field has reflected through the formation of a number of art schools such as study Art and Design, MARA Institute of Technology (ITM), which became one of the pioneers of art education institutions in Malaysia. Efforts to develop a local community committed to respond to the nation's development agenda. Since founded in 1967 , the formation of curriculum approaches and trends of visual arts education and cultural agenda of the country has been taken into account.

In addition, the Philosophy in Education as well as nation, the important cultural events such as the formation of the National Cultural Policy (1971), Seminars on the Roots of Indigenous Arts and Their Present Development (1979), and the rise and the tendency toward Islamic values have also influenced the curriculum development and the development of art in Malaysia in general. The formation of the National Cultural Foundation has also recommended that the search of national identity based on local indigenous culture has driven the artists and designers to refer to the 
traditional arts as their source of inspiration. For the cartoonist, the search has made them possible to refer to the life and culture surroundings as an inspiration, as Lat did in his masterpiece The Kampung Boy (1979) "The Boy Village"(Illustration 8.5).

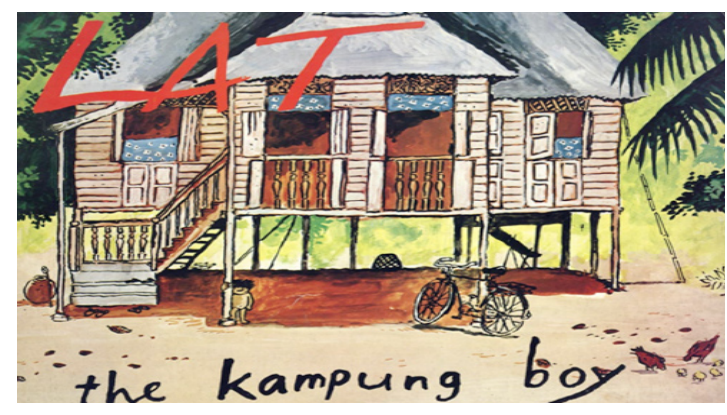

Illustration 8.5. Lat, The Kampung Boy, 1979.

This was reinforced by organizing seminars on the Roots of Native Arts that keep track on beauty and meaning of traditional art forms. The rise of Islamic values in the 1980's has also seen the introduction of Islamic Art subjects at ITM in 1982 and the emergence of more Islamic work has been created by instructors such as Sulaiman Esa, Ahmad Khalid Yusof, Hashim Hassan, Ponirin Amin, Zakaria Awang, and Ruzaikha Omar Basaree.

The role of Art and Design in developing nations are also seen in the context of its relationship with the National Education Philosophy that becomes a core in the curriculum development. As the following excerpt, the National Education Philosophy emphasizes the balanced development of the individual in shaping society and a peaceful nation.

"Education in Malaysia is an ongoing effort towards further developing of the individual potentials in holistic and integrated ways, in order to create a balanced and harmonious intellectually, spiritually, emotionally, and physically based on the belief in and devotion to God. Effort is designed to produce Malaysian citizens who are knowledgeable, competent, honorable, responsible, and capable of achieving well-being and contribute to the harmony and prosperity of society and the nation "(National Education Philosophy).

In this context, for Malaysia, the role of the field of Art and Design covers the problemss that are actually relevant to the development of the individual and society, which at the same time in line with Asian values.

\section{The Role Art and Design Fields in Malaysia}

In this new millennium, the problem of local and global values or identities often become an important issue for artists and cartoonists, of course, without neglecting the role of economic and commercial values. This is consistent with the theme of this seminar, which also emphasizes the search for identity in the formation of the Asian community. In Malaysia, commercial and industrial aspects of the art are not marginalized, but many programs planned by the government generate the local creative industry such as the creation of the National Creative Industry Policy, National Creative Industry Fund, and various other incentives.

In addition to the involvement of the industry, government support is also very important in determining the direction and continuity of art and design. The Malaysian Government established Art School in Johor and Sarawak in 2007 and declared the year 2010 as a year of 
innovation and creativity that is known as the Malaysia Innovative 2010 to endorse the government's culture of innovation and creativity that is so synonymous with the world of art and design. Organizing various activities and initiatives that lead to the creation and product design among the general public and students who demonstrate the visual arts that have the potential and demand.

In this context, the establishment of bodies related to art such as the Malaysia Design Council (MRM) under the auspices of the Ministry of Science, Technology and Innovation (MOSTI) in 1993 is seen as positive. The agency plays a role as a promoter, counselor, and the innovation activities among the people. Among others, to ensure product design locally to compete globally, MRM focuses on three key roles, namely, "to give recognition to the creation potential and competitiveness, to provide educational programs to researchers new from among students school and university students, and provide a platform for competition to evaluate the product, to encourage more innovation creation produced "(Ahmad Zainuddin in Nazrul Azim Sharuddin, May 26, 2010: 4).

The progress of Art and Design Education directly correlated with the national development agenda, thus the potential is great and convincing. In addition to efforts, strong academic staff, support from the government and industry will most certainly boost the potential of this area as a whole.

It is generally associated with the physical aspect, but what about the spiritual, especially in questions of meaning, value and artistic expression itself? In the context of the cartoon art, the issue is related to the question of tree theme, style, appearance and methods of criticism? How can these things be linked and utilized by the Asian community? Could the existence of a uniform nature of the underlying themes, styles and methods belong to Asia criticism?

\section{Local and Global Styles in Lat Cartoons}

Mix 2012 Comics Symposium held at the Columbus College of Art \& Design, USA, in October 2012 has featured four interesting major themes: "The Epic Ordinary: Contemporary Life and the Epic Narrative in Comics; Extraordinary Epics: Reshaping History and Myth in Contemporary Comics; Dimensions of Gender: Depictions of Sex, Sexuality and Gender in Comics and Sustainability or Apocalypse? Imagining the Future through Comics" (Columbus College of Art \& Design).

The symposium theme of visual themes lie actually across the global cartoons and comics. How does the story of ordinary daily life can be lifted up as a great epic; reforms the history and legend into great and exceptional works; discusses gender issues and the problems of the future in the context of environmental issues. These themes are fascinating to be comprehended by the comic and cartoon artists in drawing their creative works. In addition to finding the right and match style suitably applied in Asia, how meanings and messages can also be effectively and properly expressed.

Community and cultural pluralism of Asia actually provide a great source of inspiration for great Asian cartoonists 
to produce quality work. From rich and various types of folklores, storytellers, oral traditions and daily life can all be turned into one of visual themes and subjects which will never break and run out.

For Malaysia, the best exampleis thework of renowned cartoonist, Lat with his work The Kampung Boy (1979) (Illustration 6) that lift the daily life of the rural communities in publicly acceptable forms and performances. The story of this ordinary life can be turned into an enduring masterpiece of old and time-tested sound, translated into various languages, thus allowing the Asian values appreciated by the global community. tUnderstand and respect the values of the multi-ethnic culture is a way in which Asian societies can understand each other in creating a desired Asian community.

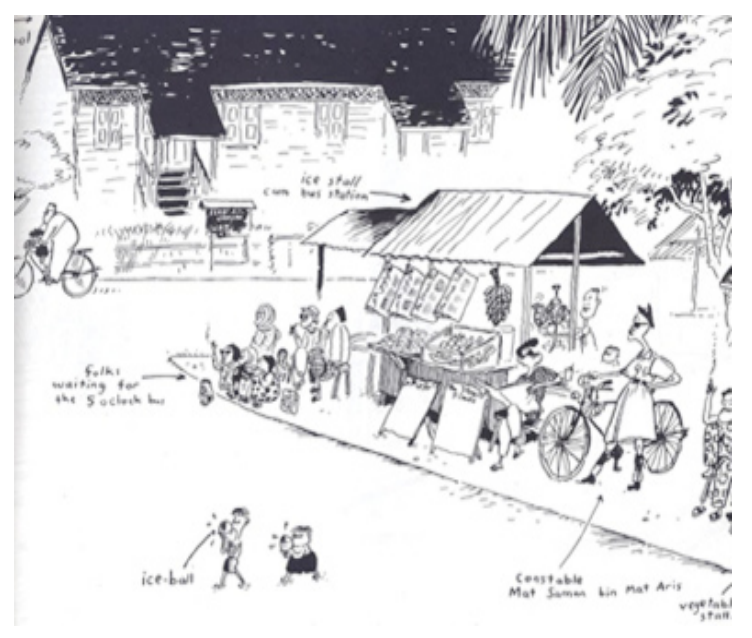
1979.

Illustration 8.6. Lat, The Kampung Boy,

The question of national identity, as well as a plural society of Malaysia is key issues in the Lat story. Among other things, factors that contribute to the strengthening
Lat cartoons, including the sensitivity to the diversity of customs and traditions of a society of Malaysia; concern for the cultural aspects of dying Malaysia; the themes of political and social life and neutrality; appearance issues of international issues in the context of Malaysia; as well as humor and subtle satire reacted to flaws that exist in society in general. Lat ways in criticizing the ethics and aesthetics have met the subtle, more layered symbolic Malay criticisms.

"Keluarga Si Mamat" grasps the subject and includes questions on current issues, thus shows sensitivity of Lat on local and contemporary issues that has been established in the works of lerang slopes cartoon before creeping in editorial cartoons "Scenes of Malaysian Life" in the New Straits Times.

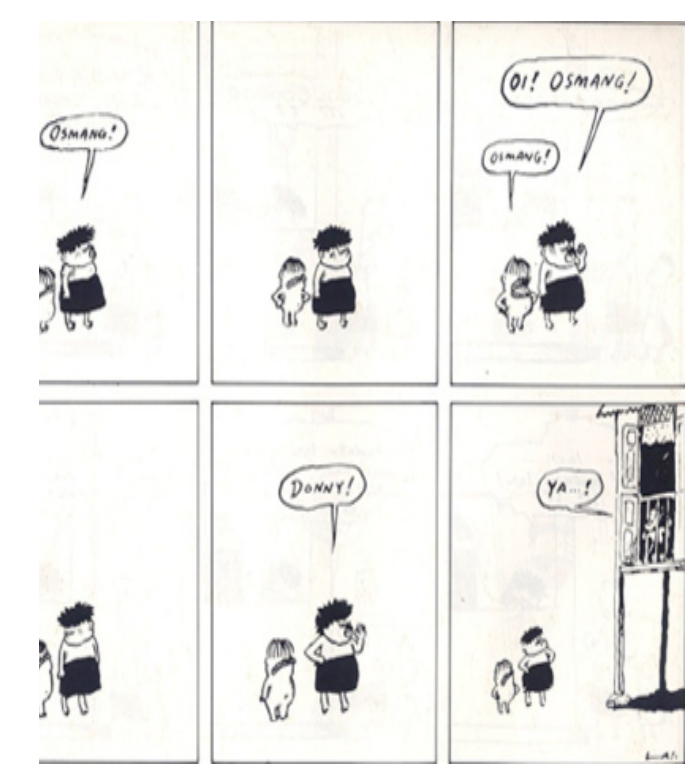

Illustrasion 8.7. Lat, Keluarga Si Mamat. 1979.

In addition, Lat has produced any other important works in a form of books 
as Kampung Boy (1979), Town Boy (1980), Mat Som (1989), Kampung Boy-Yesterday and Today (1993), and over 20 anthologies editorial cartoons. In Kampung Boy, village atmosphere is described with such delicate and detailed imagery through imaged-house and neatly painted flora. Other than reflecting life experiences, Kampung Boy reflects the values of subtly beautiful countryside of Malay culture, such as family love and friendship: as a reflection of the universal value of Asia.

In addition, slopes cartoons and books, of Lat's multiracial sensitivity to Malaysia has also reflected in editorial cartoons featuring self-portraits and caricatures of the figures, and several characters who often appear like an old lady, bald male of Chinese, stocky with spectacled man of India, Sikh men and Malay couples in scooter.

These characters have become trademarks in his cartoons and reflected the country's ethnic diversity and Lat's sensitivity against racial and cultural diversity of Malaysia. Lat masterpieces show that he is an employee who is sensitive and concerned to the current developments, the identity of the people, the diversity of customs, cultures and traditions of the plural society of Malaysia. Through various genres of cartoons, Lat shows attributes or characteristics of the unique and special nature of the core and symbol of the Malaysian and the Asian communities, thus making the reflection of his Malaysian and Asian faces. Lat works such as Town Boy (1980) (Illustration 8) also discusses multi ethnic and cultural aspects of the characters learned from the lives of the children. It is clear that tolerance should be inculcated from childhood as a basis to understand each other.

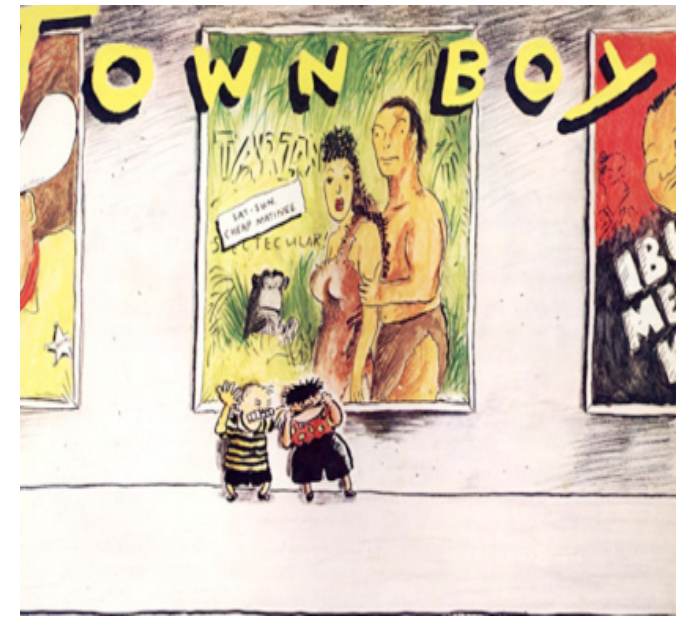

Illustration 8.8. Lat, Town Boy, 1980.

This is also reflected in the works of Lat editorial cartoon that also reflects the multiethnic characters as a reflection of society. Through Lat cartoon, the world community recognize Malaysia's multi-ethnic nature and culture. The multiculture of Asia is indeed the pluralistic nature and diversity that should thankfully be celebrated by taking into account values, customs and morality of the society. This includes the way of conveying subtle symbolic and prudent criticism (Illustration 8.9).

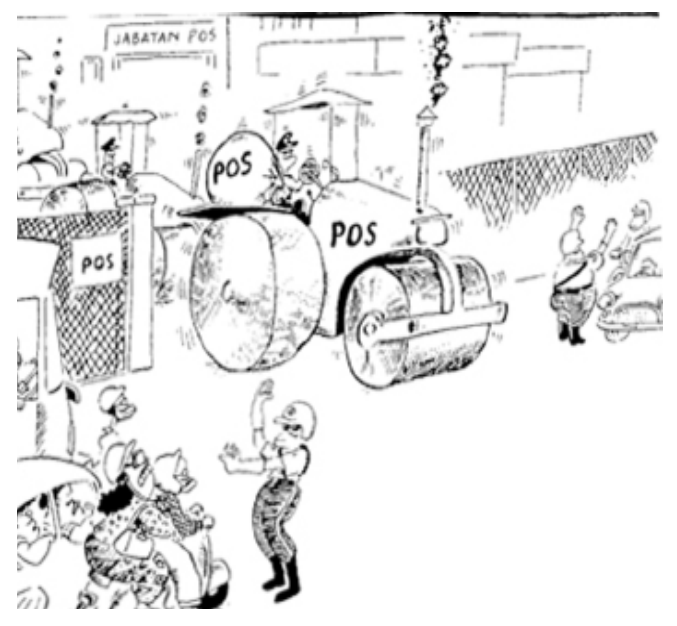

Illustration 8.9. Lat, Lat Was Here, 1995. 
Lat success lies in the attitude of a lot of visual, as he said during the declaration Fukuoka Arts and Culture awards in 2002, that "Cartoons are the most effective media of communication in the world. Via cartoons, we strive to understand each other in a positive and honest way" (Muliyadi Mahamood, 2010: 120).

\section{Conclusion}

Since before independence until the emergence of Lat's works, eastern spirit was evident in the works of grasping the question of socio-political cartoon in Malaysia through a variety of approaches appropriate to the era. Nevertheless, the works of Lat clearly has its own privileges in showing a plural and multiculture society. Lat's determination in understanding aspects of the community in a positive culture can become an example and a model for strengthening the role of cartoons in the formation of the Asian community because only with mutual respect and understanding of each other, the only cultural unity of spirit can be created.

\section{REFERENCES}

Abd.Hamid, M. A., Hasan, Z, Khalid, E., and Abu Kassim. (2007). Pendidik kreatif sebagai teras transformasi kreatif di Malaysia. Fakulti Pengurusan dan Pembangunan Sumber Manusia, Universiti Teknologi Malaysia. Adam, A. (1992). Sejarah dan Bibliografi Akhbar dan Majalah Melayu Abad Kesembilan Belas. Bangi: Penerbitan Universiti Kebangsaan Malaysia.
Ahmad, Z.A. (1941). Malay Journalism in Malaya. Journal of the Malayan Branch of the Royal Asiatic Society, Vol.XIX:244-250.

Ahmad, Z.R. (1995). Wawancara: Kartun Mekanisme Intelektual-Lat. Mingguan Malaysia. Kuala Lumpur: Utusan Melayu (M) Bhd.

Amanina, S. (2010). "Industri Kreatif Memacu Ekonomi" dalam Dewan Ekonomi. Kuala Lumpur: Dewan Bahasa dan Pustaka, ms. 55-56.

Behrendt, F. (1975). "The Freedom of the Political Cartoonist" dalam 2oth Century Studies; Politics in Cartoons and Caricature. Canterbury: The Faculties of Humanities and Social Sciences, University of Kent.

Brooks, R. (1993). The effective teaching of History. Longman Group, UK.

Brown, R. (1995). Managing the learning of History. London: David Fulton Publishers.

Columbus College of Art \& Design. MIX. (2012). Comics Symposium. Mix Comics Symposium@ccad.edu

Fernie, E., (1995). Art History and its Methods: A Critical Anthology. London: Phaidon.

Gombrich, E. H., (1963). "The Cartoonist's Armoury" in Meditations on a Hobby Horse and Other Essays on the Theory of Art. London: Phaidon Press.

Hoff, S., (1976). Editorial and Political Cartooning. New York: Stravon Educational Press

Horn, M. (ed.), (1981). The World Encyclopedia of Cartoons. New York: Chelsea House Publishers. 
Ibrahim, A. (1997). Gelombang Kebangkitan ASIA. Kuala Lumpur: Dewan Bahasa dan Pustaka

Institut Tadbiran Awam Negara (INTAN)

Malaysia. (1994). Dasar-dasar

Pembangunan Malaysia.

Ishak, H. M. (1938). Putera Gunung

Tahan. Petaling Jaya: Penerbitan

Pustaka Budaya Agency.

Iskandar, A. (1980). Persuratkhabaran

Melayu 1876-1968. Kuala Lumpur:

Dewan Bahasa dan Pustaka.

Kementerian Pendidikan Malaysia,

(2000). Sukatan Pelajaran Kurikulum

BersepaduSekolahRendah.Pendidikan

Seni Visual.

Kementerian Pendidikan Malaysia.

(2000). Sukatan Pelajaran Kurikulum

Bersepadu Sekolah Menengah:

Pendidikan Seni Visual.

Lat. (1979). The Kampung Boy. Kuala

Lumpur: Berita Publishing Sdn. Bhd.

Lat. (1979). Keluarga Si Mamat. Kuala

Lumpur: Berita Publishing Sdn. Bhd.

Lat. (1980). With A Little Bit of Lat. Kuala

Lumpur: Berita Publishing Sdn. Bhd.

Lat. (1983). Lat and His Lot Again. Kuala

Lumpur: Berita Publishing Sdn. Bhd.

Lat. (1985). Entahlah Mak...! Kuala

Lumpur: Berita Publishing Sdn. Bhd.

Lat. (1985). It's A Lat Lat Lat Lat World.

Kuala Lumpur: Berita Publishing Sdn.

Bhd.

Lat. (1987). Lat and Gang. Kuala Lumpur:

Berita Publishing Sdn. Bhd.

Lat. (1989). Better Lat Than Never. Kuala

Lumpur: Berita Publishing Sdn. Bhd.

Lat. (1990). Lat As Usual. Kuala Lumpur:

Berita Publishing Sdn. Bhd.
Lat. (1992). Be Serious! Kuala Lumpur: Berita Publishing Sdn. Bhd.

Lat. (1994). "Lat on Lat" in Lat. (1994). Lat 30 Years Later. Petaling Jaya: Kampung Boy Sdn. Bhd.

Lat. (1994). Lat 30 Years Later. Petaling Jaya: Kampung Boy Sdn. Bhd.

Lat. (1995). Lat Was Here. Kuala Lumpur: Berita Publishing Sdn. Bhd.

Lat. (2004). Dr. Who? Kuala Lumpur: Berita Publishing Sdn. Bhd.

Lent, J.A. (1994). Of 'Kampung Boy,' 'Tok

Guru' and Other Zany Characters: Cartooning in Malaysia. Jurnal Komunikasi, 10:55-77

Lent, J. A., ed. (2001). Animation in Asia and the Pacific. London: John Libbey.

Lent, J. A. (2003). Cartooning in Malaysia and Singapore: The Same, but Different in International Journal of Comic Art. Vol. 5, No. 1, Spring 2003, ms. 256-289.

Majlis Peperiksaan Malaysia, (2005). Sukatan Pelajaran dan Soalan Contoh Peperiksaan Sijil Tinggi Persekolahan Malaysia (STPM): Seni Visual.

Mingguan Malaysia, 1990-2005. Kuala Lumpur: Utusan Melayu (M) Bhd.

Mohd. S.H. (1996). Akhbar dan Kuasa: Perkembangan Sistem Akhbar di Malaysia Sejak 1806. Kuala Lumpur: Penerbit Universiti Malaya.

Muliyadi, M. (1990). A Brief History of Malaysian Cartoons in International Cartoonists Gathering. Kuala Lumpur: Kampung Boy Sdn. Bhd.

Muliyadi, M. (1997). The Development of Malay Editorial Cartoons in Southeast Asian Journal of Social Science. Volume 25, Number 1 (1997), ms.37-58. 
Muliyadi, M. (1997). Malay Editorial Cartoons: The Development of Style and Critical Humour. Ph.D Thesis, University of Kent at Canterbury, Kent, England.

Muliyadi, M. (1999). Pengantar Seni Lukis Kartun. Kuala Lumpur: Univision Press

Muliyadi, M. (1999). Kartun dan Kartunis. Kuala Lumpur: Univision Press.

Muliyadi, M. (2001). "The History of Malaysian Animated Cartoons" dalam Lent, J. A., ed., 2001. Animation in Asia and the Pacific. London: John Libbey.

Muliyadi, M. (2003). Tema Kemelayuan dalam Kartun Lat in Dewan Budaya. Kuala Lumpur: Dewan Bahasa dan Pustaka, April 2003, ms. 40-42.

Muliyadi, M. (2003). An Overview of Malaysian Contemporary Cartoons" dalam International Journal of Comic Art. Vol. 5, No. 1, Spring 2003, ms. 292 $-304$.

Muliyadi, M. (2004). The History of Malay Editorial Cartoons (1930s-1993). Kuala Lumpur: Utusan Publications and Distributors Sdn Bhd.

Muliyadi, M. (2010). Kartun Editorial Melayu sejak 199o. Shah Alam: Upena.

Piyadasa, R. (1981). Pengolahan Lanskap Tempatan dalam Seni Moden Malaysia 1930-1981. Kuala Lumpur: Muzium Seni Negara.

Piyadasa, R. (1994). "The Cartoonist - An Appreciation and Tribute" dalam Lat, 1994. Lat 30 Years Later. Petaling Jaya: Kampung Boy Sdn. Bhd.
Printing Presses and Publications Act, 1984,1993. Kuala Lumpur: International Law Book Services.

Sharuddin, N.A. (2010). MRM Galak Rakyat Ceburi Bidang Reka Bentuk" dalam Estidotmy. Kuala Lumpur: Utusan Melayu (M) Bhd.

Piyadasa, R. and Muliyadi, M. (2004). Pameran Retrospektif Lat. Kuala Lumpur: Balai Seni Lukis Negara.

Seymour-Ure, C. (1975). How Special Are Cartoonists?" in 2oth Century Studies; Politics in Cartoon and Caricature, ms.6-21. Canterbury: The Faculties of Humanities and Social Sciences, University of Kent.

Seymour-Ure, C. (1986). "Drawn and Quartered : The Election in Cartoons' in Political Communications: The General Election Campaign of 1983. Crewe, I. And Harrop, M. (ed), 1986. Cambridge: Cambridge University Press.

Seymour-Ure, C. (1996). The Editorial Cartoon in the Contemporary British Press : Change or Decay? in Mots. Vol.48.

Sommerlad, E. L. (1966). The Press in Developing Countries. Sydney: Sydney University Press.

Sweeney, A. (1976). The Pak Pandir Cycle of Tales. Journal of the Malaysian Branch of the Royal Asiatic Society, 299:15-62.

Tang, G. L. (2006). Penerokaan teknik dan pendekatan yang sesuai dalam proses membantu pelajar menyiapkan Kajian Sejarah Tempatan. Jurnal Penyelidikan Tindakan Tahun 2006. Jilid 1 (pp. 73 - 90). 
Warta Jenaka, 1936. Singapura: Warta Malaya Press Ltd.'

Watts, R. and Grosvenor, Ian (eds.) (1995), Crossing the Key Stages of History: Effective History Teaching 5-16 and beyond, David Fulton, London.

Wilmott, J. R.(1989). Lat: Malaysia's Favorite Son. Hong Kong: Reader's Digest Association Far East Ltd.
Zakaria, A. (1989). Seni dan Seniman. Kuala Lumpur: Dewan Bahasa dan Pustaka.

Zakiah, H. (1989). Senda, Sindir, Sengat. Petaling Jaya: Lajmeidakh Sdn. Bhd. Zulkifli, M. (1979). Warta Malaya; Penyambung Lidah Bangsa Melayu 1930-1941. Bangi: Jabatan Sejarah UKM. 